\title{
MISSING LINK KOTA DEPOK \\ (Case Study: Management Missing Link at Kota Depok)
}

\author{
Muksin Jalil \\ Civil Engineering Departemen Ibn Khaldun University Bogor, INDONESIA \\ E-mail: muksinjali167@gmail.com
}

\begin{abstract}
In connection with the important role of the road network and connectivity of public transport in the area of the City of Depok, there is a problem called the missing link. The purpose of this study is reviewed from the aspects of road network performance, connectivity of activity centers, TOD areas and transportation nodes, then obtained by loading the Origin Destination Matrix (MAT) to the road network with the help of transportation modeling software using Saturn. Travel speed between cities / regencies in Jabodetabek or the origin destination of Depok City does not reach the target speed of $40 \mathrm{~km} /$ hour, and speeds between regions and within regencies/cities in Depok city. Tangerang Regency and Bekasi Regency have the lowest speeds, with the lowest values being $25.06 \mathrm{~km} / \mathrm{hour}$ and $25.39 \mathrm{~km} /$ hour. So that the need to increase the capacity of the road network to and from Tangerang and Bekasi districts, for Depok city the average speed that occurs within the city is 28.81 $\mathrm{km} / \mathrm{hour}$, so it is necessary to increase the capacity of the road network. The TOD area will have a missing link if the TOD has no connectivity with the mass transit node at a distance of more than 800 meters and is not on the main high-capacity mass transit line, such as the Cinere TOD. The need for handling the missing link TOD area of the road network in the Greater Jakarta area, mainly Cinere - Fatmawati Station. And there is PKN that is not connected by public transportation to other PKN and is not connected with PKW in the same City, namely Cimanggis District, Depok City.
\end{abstract}

Key word: TOD; public transport; speed; MAT; transit.

\begin{tabular}{cccc}
\hline Received: & Revised: & Accepted: & Available online: \\
2020-03-04 & $2020-11-09$ & $2020-11-11$ & $2021-03-29$ \\
\hline
\end{tabular}

\section{INTRODUCTION}

The road network is a land transportation infrastructure that plays an important role in the transportation sector, especially for the sustainable distribution of goods and services. In urban and district planning and development, road facilities as one of the backbones of transportation are an integral part (Anonim, 2009).

With the changing times and the increasing use of land transportation, especially road transportation, the government is increasingly confused by the congestion that occurs. The road infrastructure network consists of nodes in the form of terminals, both passenger and freight terminals and traffic space. The traffic space in road transportation is in the form of roads which are hierarchically determined according to their roles, consisting of arterial roads, collectors and local roads. So far the government has planned various efforts to tackle traffic problems. Depok City is one of the cities that is included in West Java Province (West Java Governor Decree, 2011); (Law on Road, 2009); (Warpani S, 1990). This city is located in the south of DKI Jakarta Province. Depok City is a city administrative area originating from the pamekaran administrative area of Bogor Regency in 1982. Depok City is one of the suburbs of the DKI Jakarta Province, which is the city administrative area directly adjacent to the DKI Jakarta Province so that Depok City is directly affected by the multiplier effect of spatial planning and infrastructure development in DKI Jakarta Province.

Geographically, Depok City is located at the coordinates $6^{\circ} 19^{\prime} 00$ " $-6^{\circ} 28^{\prime \prime} 00$ "' LL and $106^{\circ} 43$ "00" - $106^{\circ} 55^{\prime \prime 30 " ~ E a s t ~ L o n g i t u d e . ~ D e p o k ~ C i t y ~ h a s ~ a n ~ a r e a ~ o f ~} 200.29 \mathrm{~km} 2$ and is directly adjacent to the North, South Tangerang City, Banten Province and DKI Jakarta Province. While the East is bordered by Bekasi City and Bogor Regency, the South West Province is bordered by Bogor Regency, West Java Province. Depok City has 11 Districts, namely Kec. Ciamanggis, Sukmajaya, Tapos, Sawangan, Pancoran Mas, Limo, Beji, Cinere, Bojongsari, Cipayung and Cilodong. Based 
on (Central Bureau of Statistics, 2018) data, Depok City in 2018 figures in 2017, the population in Depok City was 2,254,513 people, with a male population of $1,135,539$ people and $1,118,974$ women with a sex ratio of 101.48 which means that there are 101 male population within 100 population within female. The population density in Depok City in 2017 has increased compared to 2016, which was 11,256 people $/ \mathrm{km}^{2}$, while in 2016 it had a population density of 10,883 people $/ \mathrm{km}^{2}$ (Depok City Regional and Development agency, 2011); (Depok City Regional and Development agency, 2015); (Minister of Transportation Regulation, 2015a); (Minister of Transportation Regulation, 2015b); (Minister of Transportation Regulation, 2015c).

Motor vehicle trips that apply in normal conditions are very much influenced by the condition of the vehicle and the condition of the rider (S.Syaiful, N.Wahid, 2020); (S.Syaiful, Y.Elvira, 2017).

Vehicles in good condition will make the driver comfortable, there will be no good noise generated by the engine or the vehicle supporting devices (Syaiful, Lutfi A, 2015); (Syaiful, 2015). So that you will get comfort in driving. The road that is traversed also affects the speed and speed of the vehicle, the better and smoother the road surface, the more comfortable the vehicle will be and vice versa, the easier it will be for the vehicle to maneuver, without causing the slightest noise (Thamrin, Syaiful, 2016); (S.Syaiful, A Fadly, 2020); (M Mubarak et.al, 2020); (Syaiful Syaiful, Sri Wiwoho Mudjanarko, 2019);

\section{Planning steps:}

1. Transportation System

Transportation is the activity of moving people and goods from one place to another using a mode for these activitie.

\section{Road Network Infrastructure}

Transportation infrastructure has two main roles, namely as a tool for directing development in urban areas and as an infrastructure for movement of people or goods due to activities in urban areas

\section{Road Generation}

This stage aims to study and identify the magnitude of the generation and attraction of the movement by studying several variations of the relationship between movement characteristics and the land use environment.

4. Mode Selection

This stage serves to calculate and estimate the number of flows of people or goods from the zone of origin to the zone of destination.

5. Route Selection

Aim to allocate every movement between zones to the various routes most often used by someone moving from the origin zone to the destination zone (Tamin, 2000); (Tamin, 1997); (Tamin, 2008); (Setya Lessmana, 2013).

6. Road Section Capacity

The road network capacity is the maximum traffic flow that a road network can maintain under certain conditions, which is expressed in units of passenger cars (SMP) per hour (MKJI, 1997); (Minister of Public Works Decree, 2009); (Meyrissa Putri Dewandari, 2018); (Minister of Transportation Regulation, 2015); (Government Regulation, 2014); (Government Regulation, 2006).

\section{RESEARCH METHODS}

During the first month of the study, the consultant had done several things as a first step for the overall study. Things that have been done include: 
1. Survey preparation in the form of selecting the survey method, preparing survey forms and equipment, determining the survey point and implementing Human Resources (HR).

2. Introduction of the study area in the form of development plans, institutional approaches, traffic systems, transportation facilities and infrastructure, land and environmental and socio-economic uses.

3. Updating the transportation model based on the primary survey results by calibrating the transportation model with a survey of passenger ups and downs and modal shift patterns.

4. Analysis of missing links in the three stages of missing links, namely the missing link for public transport, missing link in connecting TOD, and missing link connecting transportation nodes.

5. Primary survey of passenger ups and downs and interview survey for public transport users in Depok City.

\section{RESULTS AND DISCUSSION}

The missing link can be interpreted into 2 categories, namely the missing link on the road network and the missing link for the public transport network. Each of these categories has a different focus, where the missing link road network focuses on road network integration along with its status; while the missing link for public transport focuses on public transport connectivity, nodes, and activity centers.

1. The missing link road network is called missing if there is no road network connecting activity centers, national, local and environmental, as well as activity nodes.

2. Missing public transport links Disconnection of public transport at activity centers, nodes (terminals, ports, airports, stations) and TOD, as well as unconnected public transport integration can lead to transportation services general is not optimal and there are missing links

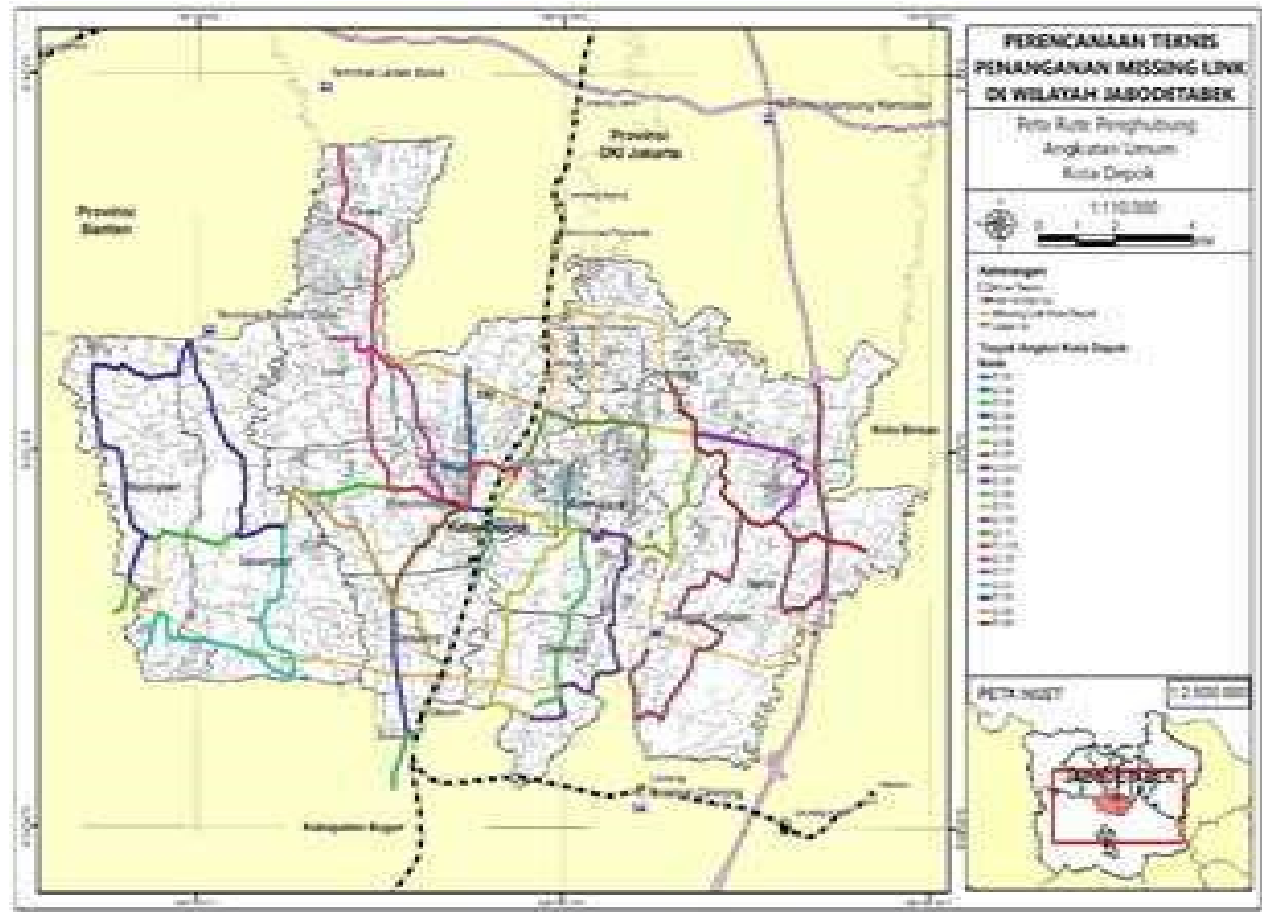

Figure 1. Missing link map for Depok Citiy. 


\section{Analysis of missing link in Depok City}

The zone of origin and destination in the Depok City network model is based on sub-districts and a combination of several sub-districts. In this case there are 11 defined zones. This zone will later affect the modeling that will be carried out, especially for the matrix of origin and destination and demand for public transport (Budi Sitorus, 2013); (VMS, 2018). The following are the zones of origin and destination on the Depok City network.

Tablel 1. The zone of origin and destination for modeling the Depok City area.

\begin{tabular}{ccc}
\hline No & Joint name of sub districts & Name of the district \\
\hline 1 & Cinere & Depok City \\
\hline 2 & Cimanggis & Depok City \\
3 & Limo & Depok City \\
4 & Sukma Jaya & Depok City \\
5 & Beji & Depok City \\
6 & Pancoran Mas & Depok City \\
7 & Tapos & Depok City \\
8 & Sawangan & Depok City \\
9 & Cipayung & Depok City \\
10 & Cilodong & Depok City \\
11 & Bojongsari & Depok City
\end{tabular}

missing link in the zone of origin and destination in question is if there is no connection to the public transport network in each zone of origin and destination zone, especially activity centers that will also be defined as PKN and PKW.

\section{Area TOD (Transit Orientedvelopment)}

Transit Oriented Development or Transit Oriented Development, which is abbreviated as TOD, is the concept of developing areas within and around mass public transportation nodes so that added value focuses on integration between mass public transport networks, and between mass public transport networks and non-motorized transportation mode networks, and reduction of motorized vehicles accompanied by the development of mixed, dense areas with moderate to high intensity of spatial use (Regulation of the Head of BPTJ No PR 377 / AJ.208 / BPTJ-2017).

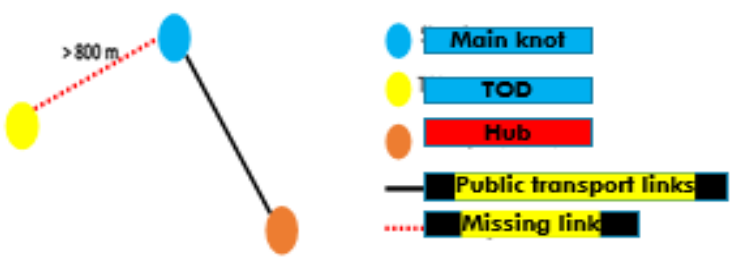

Figure 2. Ilustrasi of missing link in TOD

The TOD area will be said to have a missing link if the TOD has no connectivity with mass public transport nodes within a distance of more than 800 meters and is not on the main route for high 
capacity mass public transport. In this case, there are 2 TOD locations spread across the city of Depok as follows.

Table 2. TOD plan in Depok City.

\begin{tabular}{ccc}
\hline No & TOD location plan & City/districts \\
\hline 1 & Depok Baru & Depok City \\
2 & Cinere & Depok City \\
\hline
\end{tabular}

\section{Transportation Nodes}

The main transportation node is said to have a missing link if there are no AKAP and AKDP transportation passing through that node.

The transportation nodes must be able to connect the TOD and at each of these transportation nodes, the availability and connection of public transportation to the activity center, TOD, and other transportation nodes will be seen to analyze whether there are missing links in these transportation nodes.

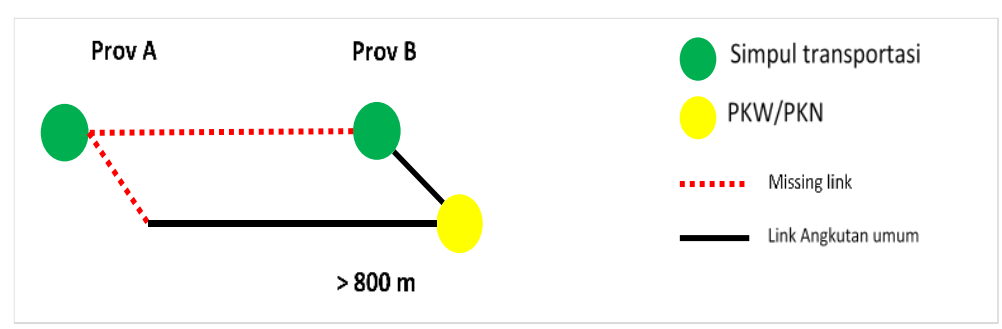

Figure 3. Ilustration missing link node.

3. Study area activity center.

Table 3. Activity center in the city of Depok

\begin{tabular}{cccc}
\hline No & Centre & Regulation_City & Name \\
\hline 1 & City Sevice centre & Depok City & Depok City \\
2 & Sub city service centre & Depok City & Cinere \\
3 & Sub city service centre & Depok City & Citayam \\
4 & Sub city service centre & Depok City & Sawangan \\
5 & Sub city service centre & Depok City & Cimanggis \\
\hline
\end{tabular}


The activity center is an area that serves activities in an area in relation to other areas on a certain scale. In this case, there are several types of activity centers, namely National Activity Centers (PKN) and Regional Activity Centers (PKW) and Local Activity Centers (PKL). The following are activity centers in Depok City:

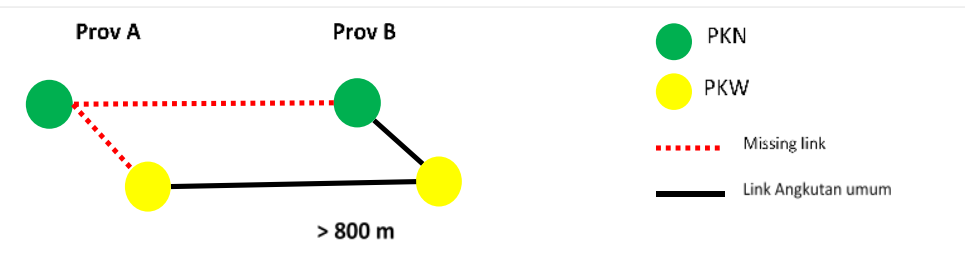

Figure 4. Ilustration of missing link activity center.

In this case there are 5 PKW (Regional Activity Centers) in the Depok City area as follows:

4. The AKAP route (Between cities between Provinces).

Table 4. Depok City transportation route

\begin{tabular}{|c|c|c|}
\hline No & Route code & Route \\
\hline 1 & D 01 & Depok terminal-Depok I \\
\hline 2 & D 02 & Depok terminal-Depok II center/east \\
\hline 3 & D 03 & Depok terminal-Parung \\
\hline 4 & D 04 & Depok terminal-Beji-Kukusan \\
\hline 5 & D 05 & Depok terminal-Bojong Gede \\
\hline 6 & D 06 & Depok terminal-Pasar Cisalak \\
\hline 7 & D 07 & Depok terminal-Pitara-Rawa Denok \\
\hline 8 & D 07A & Depok terminal-Pitara-Citayam \\
\hline 9 & D 07A & Depok terminal-Pitara-Citayam \\
\hline 10 & D 08 & Depok terminal-BBM-Kp. Sawah \\
\hline 11 & D 09 & Terminal Depok-Studio Alam-Kp. Sawah \\
\hline 12 & D 10 & Depok terminal-Parung Serab-Kp. Sawah \\
\hline 13 & D 11 & Depok terminal -Akses UI-Palsi Gunung \\
\hline 14 & D 15 & Depok terminal-Jl.R. Sanim-Simpang Limo \\
\hline 15 & D 21 & Sawanga-Duren Seribu \\
\hline 16 & D 25 & Bedahan-Sawangan-Curug-BSI \\
\hline 17 & D 26 & Sub Sawangan terminal-Citayam \\
\hline 18 & D 17 & Jatijajar-Banjaran Pucung-Tapos \\
\hline 19 & D 107 & Ps.Cisalak-Gas Alam- Leuwinanggung \\
\hline 20 & D 69 & Ps.Cisalah-Pekapuran-Bayunan \\
\hline 21 & D 110 & Terminal Depok-Cinere \\
\hline
\end{tabular}


Intercity and Interprovincial Transportation is public transportation that serves trips from one city to another city with different provinces. In this case, AKAP transportation generally uses the bus mode with rates that vary depending on the distance from the origin and destination cities. AKAP usually leads to a type A terminal in an area and has the last stop at terminal A as well. AKAP routes are detailed in the attachment.

Table 5. The AKAP route in the area.

\begin{tabular}{cll}
\hline No & \multicolumn{1}{c}{ Routes } & Type \\
\hline 1 & Blok M-Cinere & AKAP \\
2 & Blok M-Depok & AKAP \\
3 & Lebak Bulus-Depok & AKAP \\
4 & Pondok Labu-Depok & AKAP \\
5 & Grogol-Depok & AKAP \\
6 & Sawangan terminal-Ciputat & AKAP \\
7 & Depok-Kp.Rambutan & AKAP \\
8 & Simpangan Depok-Kampung Rambutan & AKAP \\
9 & Depok Timur-Kp. Rambutan & AKAP \\
10 & Depok-Kp.Rambutan & AKAP \\
11 & Kp. Rambutan-Depok & AKAP \\
12 & Depok-Bandara Halim Perdana Kusuma & AKAP \\
13 & Mayasari Bakti AC84 Pulo Gadung-Depok & AKAP \\
14 & Jatijajar terminal-leuwinanggung & AKAP \\
\hline
\end{tabular}

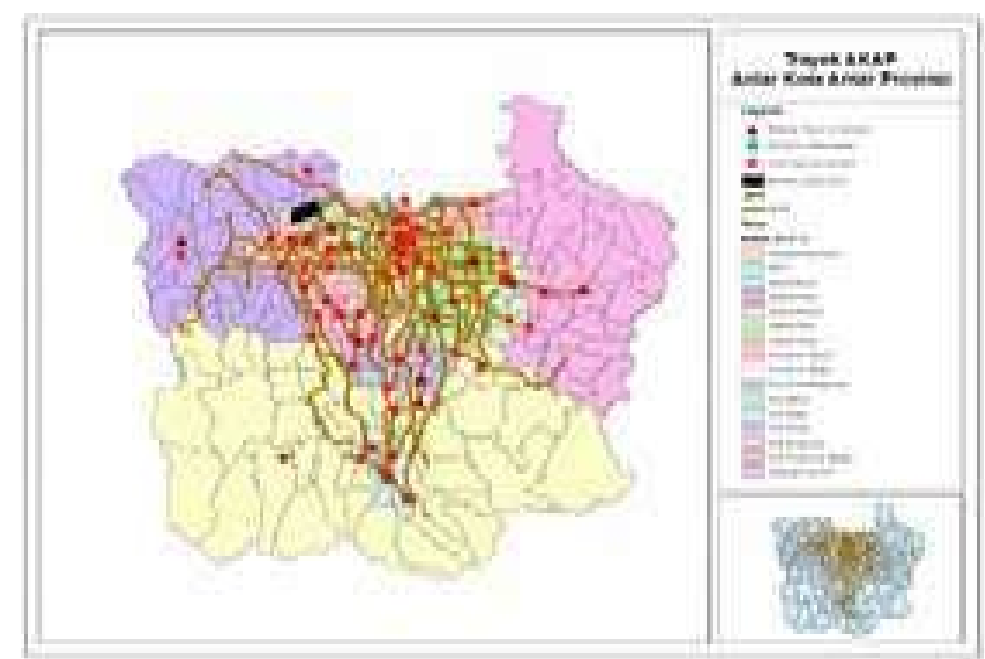

Figure 5. Jabodetabek AKAP routes.

From the figure below, it can be seen that AKAP routes in the Jabodetabek area have mostly served activity centers in Jabodetabek and TOD, but there are several node locations, especially terminal A which have not been served by AKAP. 


\section{Depok city transportation route.}

Depok city transportation route is in the form of public transportatioj with rates that vary according to the distance traveled. There are 21 transportation routes for Depok City. The following is the transportation route for Depok City.

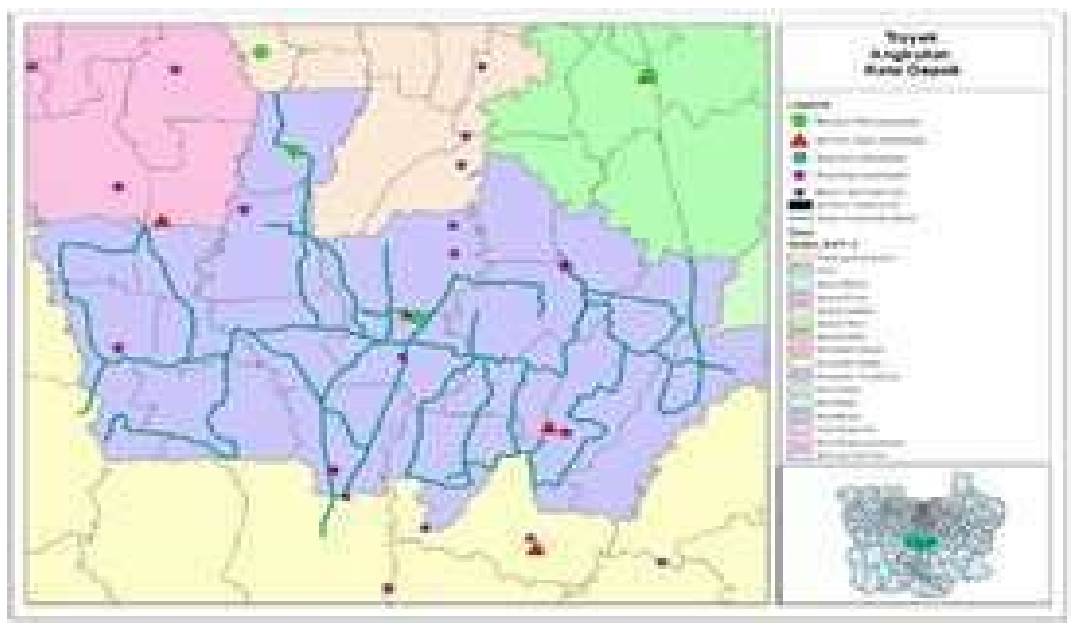

Figure 6. Depok City Transportation Route Map.

\section{Discussion of Missing Road Network Links.}

In general, the road network in Jabodetabek has connected activity centers, national, local, and environmental. The target speed that has been set, with a special value for Jabodetabek is a minimum network speed of $20 \mathrm{~km} /$ hour. On average, based on the modeling results that have been submitted, the Jabodetabek average network speed has met the target. However, if it is examined in more detail per road function, with the minimum speed criterion for arterial and collector roads being $40 \mathrm{~km} /$ hour, a more detailed review is carried out on the speed between regions and within the lowest district / city in Depok City. Tangerang Regency and Bekasi Regency had the lowest speed, with the lowest values being $25.06 \mathrm{~km} /$ hour and $25.39 \mathrm{~km} /$ hour. This indicates the need to increase the capacity of the road network to and from Tangerang District and Bekasi District. For Depok City, information on the average speed that occurs in the city is $28.81 \mathrm{~km} /$ hour, so it is necessary to increase the capacity of the road network in Depok City.

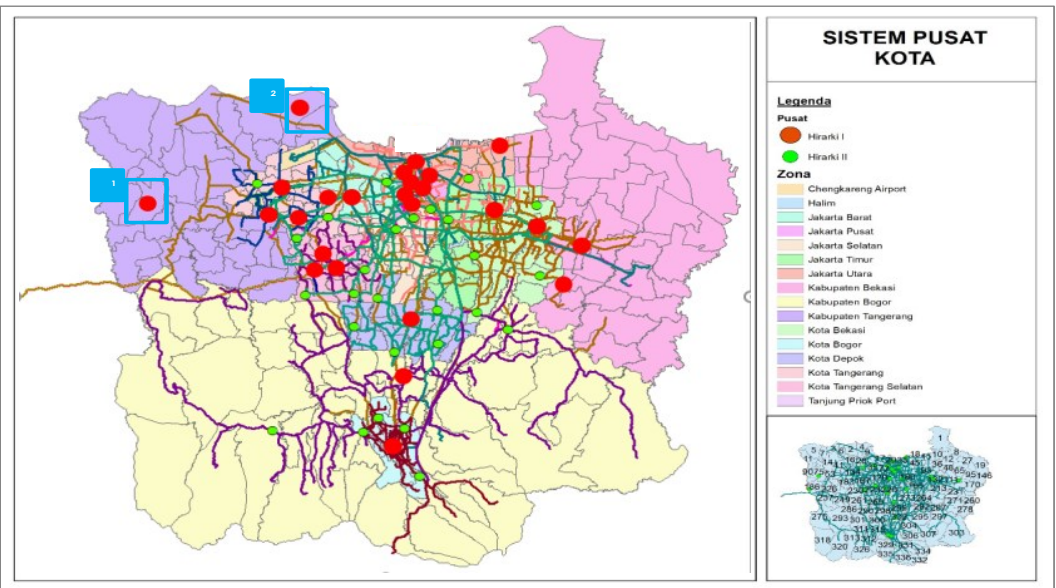

Figure 7. Activity center for public transport and its integration into nodes. 
Table 6. Closest TOD distance

\begin{tabular}{cl}
\hline TOD namely and distance closest & Range \\
\hline TOD Cinere - Fatmawati station & $6,1 \mathrm{~km}$ \\
\hline
\end{tabular}

\section{Analysis of Missing Link Activity Center.}

From the picture above, it can be seen that there are 5 PKNs that are not connected by public transportation to other PKNs and are not connected to PKW in the same city. one PKN is not connected at all by public transport routes, resulting in a missing link. The one PKN is:

\section{Cinere sub-district, Depok city.}

2. Citayam sub-district, Depok city.

3. Sawangan sub-district, Depok city.

4. Cimanggis sub-district, Depok city.

\section{Depok city.}

For PKN one, Kecamatan Tapos, if you want an addition of public transportation routes, preferably connecting PKN Tapos with other PKNs in other cities / districts (at least the closest), for example public transportation routes that connect PKN Tapos with PKN Depok City or, add public transport routes that can be directly connected from PKN Tapos with the train station. In addition, it can be done rerouting the nearest public transport or recommended routing of public transportation close to the train route. In addition, routing can also be done for the following routes: AKAP Jatijajar terminal

Table 7. Ilustration of connectedness to national activity centers.

\begin{tabular}{clc}
\hline PKN & PKN - PKN (No mass public transportation) & Range \\
\hline PKN Cimanggis & $\begin{array}{l}\text { PKN Cimanggis-AKAP (Terminal Jatijajar- } \\
\text { Depok city) }\end{array}$ & \\
& & \\
\end{tabular}

\section{Missing link analysis for the TOD region}

In the first criterion, the distance between the TOD and the transportation node is a maximum of 800 meters. From the images and analysis of the 800 meter buffer for TOD that has been carried out, it can be seen that there are still several TODs that are more than 800 meters from the transportation node, namely:

\section{Cinere}

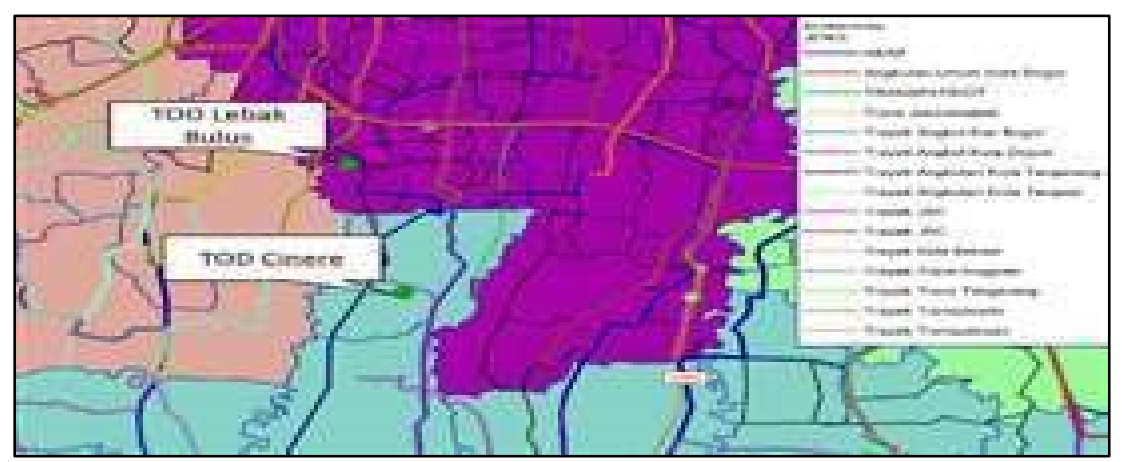

Figure 8. The distance of the TOD and the closest node. 


\section{Transportation Node Missing Link Analysis.}

The main transportation node is said to have a missing link if it is not connected to the AKAP and / or AKDP public transport routes. The following is a map of public transport routes that have been previously identified along with transportation nodes.

From the picture above there is one node that is not at all integrated with public transport, namely Terminal type A Jatijajar. Where this terminal is not connected to public transportation at all, this terminal is located between the nearest public transport route.

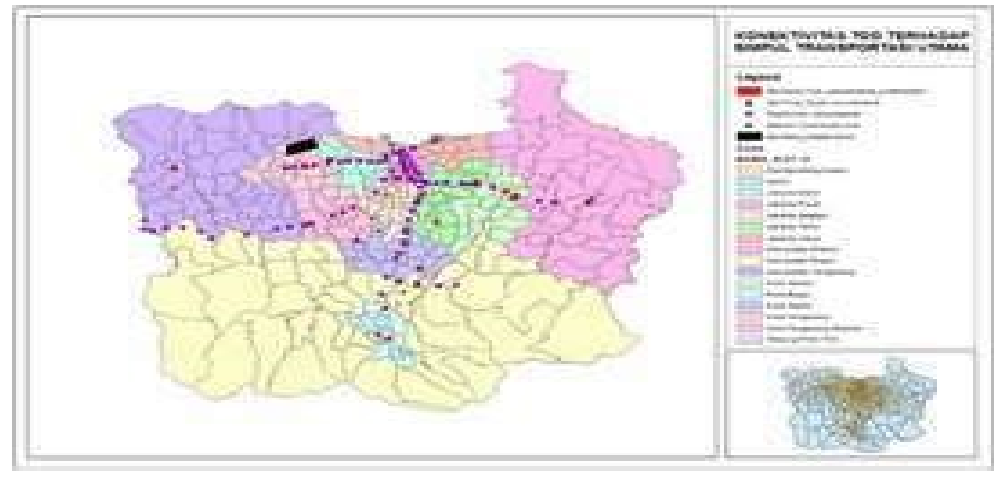

Figure 9. Transport routes in the Jabodetabek area.

Table 8. Missing links and recommendations for public transport networks

\begin{tabular}{|c|c|c|c|c|c|}
\hline $\begin{array}{l}\text { Missing } \\
\text { Link on: }\end{array}$ & Criteria & \multicolumn{2}{|c|}{$\begin{array}{c}\text { Existence of the Missing } \\
\text { Link }\end{array}$} & $\begin{array}{l}\text { The Missing } \\
\text { Link } \\
\text { Description }\end{array}$ & City/District \\
\hline Network & $\begin{array}{l}\text { Network } \\
\text { speed. }\end{array}$ & $\begin{array}{l}\text { Road } \\
\text { network to } \\
\text { Tangerang } \\
\text { Regency } \\
\text { and Bekasi } \\
\text { Regency. }\end{array}$ & $\begin{array}{l}\text { Road } \\
\text { Network in } \\
\text { Depok City. }\end{array}$ & $\begin{array}{l}\text { Has the lowest } \\
\text { speed compared } \\
\text { to other speeds } \\
\text { and existing road } \\
\text { functions. }\end{array}$ & $\begin{array}{c}\text { Tangerang } \\
\text { Regency, Bekasi } \\
\text { Regency and } \\
\text { Depok City }\end{array}$ \\
\hline Hub & $\begin{array}{l}\text { In the inner } \\
\text { city network, } \\
\text { PKN and } \\
\text { PKW are not } \\
\text { connected }\end{array}$ & $\begin{array}{l}\text { Cimanggis } \\
\text { District, } \\
\text { Depok City }\end{array}$ & $\begin{array}{c}\text { PKN } \\
\text { Cimanggis- } \\
\text { AKAP } \\
\text { (Jatijajar } \\
\text { Terminal- } \\
\text { Depok City) } \\
(12 \mathrm{~km})\end{array}$ & $\begin{array}{c}\text { There is no } \\
\text { connection } \\
\text { between PKN } \\
\text { Cinere, Citayam, } \\
\text { Sawangan, } \\
\text { Cimanggis and } \\
\text { PKN Depok City }\end{array}$ & Depok City \\
\hline TOD & $\begin{array}{l}\text { First, the } \\
\text { distance } \\
\text { between the } \\
\text { TOD and the } \\
\text { transportation } \\
\text { node is a } \\
\text { maximum of } \\
800 \text { meters }\end{array}$ & $\begin{array}{l}\text { TOD } \\
\text { Cinere }\end{array}$ & $\begin{array}{c}\text { TOD } \\
\text { Ciinere- } \\
\text { Stasuin } \\
\text { Fatmawati } \\
(6.1 \mathrm{~km})\end{array}$ & $\begin{array}{l}\text { The distance of } \\
\text { the TOD and } \\
\text { transportation } \\
\text { nodes is more } \\
\text { than } 800 \text { meters. }\end{array}$ & Depok City \\
\hline
\end{tabular}




\section{Recapitulation of Missing Link of Road Network and Public Transport.}

Based on the definitions described and the analysis that has been carried out, the following is a recapitulation of missing links and recommendations for road networks and public transport.

\section{Priority for Route Handling.}

Based on the definitions that have been described and the analysis that has been carried out, the following is a recapitulation of missing links and recommendations for road networks and public transportation. After being carried out on 6 routes, the following are priorities for existing routes that must be improved services, such as additional schedules or bus fleets.

Table 9. Priorities for handling existing routes.

\begin{tabular}{|c|c|c|c|c|}
\hline No & Routes & Type of mode & $\begin{array}{c}\text { Route length } \\
(\mathbf{k m})\end{array}$ & Final score \\
\hline 1 & Univ. Indonesia-Lebak Bulus & Trans Jabodetabek & 13.4 & 0.61 \\
\hline 2 & Depok-BKN & Trans Jabodetabek & 23.04 & 0.54 \\
\hline 3 & Manggarai-Univ. & Trayek Transjakarta & 15.77 & 0.56 \\
\hline 4 & Terminal Sawangan-Ciputat & AKAP & 34.89 & 0.52 \\
\hline 5 & Depok Timur-Kp. Rambutan & AKAP & 11.07 & 0.51 \\
\hline 6 & $\begin{array}{l}\text { Terminal Jatijajar } \quad- \\
\text { Leuwinaggung }\end{array}$ & AKAP & 8.54 & 0.49 \\
\hline
\end{tabular}

For the route, it is proposed to connect between Sawangan and Ciputat Terminals. Meanwhile, the proposed city of Depok does not connect.

Table 10. Movement of public transport (pnp/day)

\begin{tabular}{|c|c|c|c|c|c|c|c|c|c|c|c|c|c|c|}
\hline $\begin{array}{c}\text { Origin/ } \\
\text { Destination }\end{array}$ & $\begin{array}{l}\text { West } \\
\text { Jakarta }\end{array}$ & $\begin{array}{l}\text { Central } \\
\text { Jakarta }\end{array}$ & $\begin{array}{l}\text { South } \\
\text { Jakarta }\end{array}$ & $\begin{array}{c}\text { East } \\
\text { Jakarta }\end{array}$ & $\begin{array}{l}\text { North } \\
\text { Jakarta }\end{array}$ & $\begin{array}{l}\text { Bekasi } \\
\text { District }\end{array}$ & $\begin{array}{l}\text { Bogor } \\
\text { District }\end{array}$ & $\begin{array}{c}\text { Tangerang } \\
\text { District }\end{array}$ & $\begin{array}{c}\text { Bekasi } \\
\text { City }\end{array}$ & $\begin{array}{l}\text { Bogor } \\
\text { City }\end{array}$ & $\begin{array}{l}\text { Depok } \\
\text { City }\end{array}$ & $\begin{array}{c}\text { Tangerang } \\
\text { City }\end{array}$ & $\begin{array}{l}\text { South } \\
\text { Tangerang } \\
\text { City }\end{array}$ & $\begin{array}{c}\text { Generation } \\
\text { Total } \\
\text { (pnp/day) }\end{array}$ \\
\hline Depok city & 8,130 & 4,698 & 9,364 & 14,474 & 4,655 & 22,035 & 55,971 & 12,306 & 8,141 & 1,967 & 299,490 & 3,815 & 2,356 & 447,402 \\
\hline
\end{tabular}

Table 11. Movement of private vehicles (vehicle/day)

\begin{tabular}{|c|c|c|c|c|c|c|c|c|c|c|c|c|c|c|}
\hline $\begin{array}{c}\text { Origin/ } \\
\text { Destination }\end{array}$ & $\begin{array}{c}\text { West } \\
\text { Jakarta }\end{array}$ & $\begin{array}{l}\text { Central } \\
\text { Jakarta }\end{array}$ & $\begin{array}{c}\text { South } \\
\text { Jakarta }\end{array}$ & $\begin{array}{c}\text { East } \\
\text { Jakarta }\end{array}$ & $\begin{array}{l}\text { North } \\
\text { Jakarta }\end{array}$ & $\begin{array}{l}\text { Bekasi } \\
\text { District }\end{array}$ & $\begin{array}{l}\text { Bogor } \\
\text { District }\end{array}$ & $\begin{array}{c}\text { Tangerang } \\
\text { District }\end{array}$ & $\begin{array}{c}\text { Bekasi } \\
\text { City }\end{array}$ & $\begin{array}{c}\text { Bogor } \\
\text { City }\end{array}$ & $\begin{array}{c}\text { Depok } \\
\text { City }\end{array}$ & $\begin{array}{c}\text { Tangerang } \\
\text { City }\end{array}$ & $\begin{array}{l}\text { South } \\
\text { Tangerang } \\
\text { City }\end{array}$ & $\begin{array}{c}\text { Generation } \\
\text { Total } \\
\text { (pnp/day) }\end{array}$ \\
\hline Depok city & 746 & 809 & 1,015 & 1,806 & 420 & 2,550 & 6,645 & 925 & 781 & 180 & 32,926 & 711 & 849 & 50,363 \\
\hline
\end{tabular}

Table 12. Speed R

\begin{tabular}{|c|c|c|c|c|c|c|c|c|c|c|c|c|c|}
\hline $\begin{array}{c}\text { Origin/ } \\
\text { Destination }\end{array}$ & $\begin{array}{c}\text { West } \\
\text { Jakarta }\end{array}$ & $\begin{array}{l}\text { Central } \\
\text { Jakarta }\end{array}$ & $\begin{array}{c}\text { South } \\
\text { Jakarta }\end{array}$ & $\begin{array}{c}\text { East } \\
\text { Jakarta }\end{array}$ & $\begin{array}{c}\text { North } \\
\text { Jakarta }\end{array}$ & $\begin{array}{c}\text { Bekasi } \\
\text { District }\end{array}$ & $\begin{array}{c}\text { Bogor } \\
\text { District }\end{array}$ & $\begin{array}{c}\text { Tangerang } \\
\text { District }\end{array}$ & $\begin{array}{c}\text { Bekasi } \\
\text { City }\end{array}$ & $\begin{array}{c}\text { Bogor } \\
\text { City }\end{array}$ & $\begin{array}{c}\text { Depok } \\
\text { City }\end{array}$ & $\begin{array}{c}\text { Tangerang } \\
\text { City }\end{array}$ & $\begin{array}{l}\text { South } \\
\text { Tangerang } \\
\text { City }\end{array}$ \\
\hline Depok city & 38,48 & 37,44 & 32,98 & 36,85 & 40,93 & 25,39 & 34,92 & 25,06 & 26,16 & 44,95 & 28,81 & 26,82 & 32,19 \\
\hline
\end{tabular}




\section{Weighting and priority handling of routes / subsidies}

In order to obtain the priority order of handling existing routes and subsidies for new routes, weighting is made of each route factor and criteria. The weighting is obtained from the average value divided by variation. Thus, even though it has a high average value, there is a greater reduction in weighting with a wider range of variations.

weighting on each of the factors and criteria. Mathematically, the calculation of the priority value for both existing and non-existing routes will be obtained by the equation:

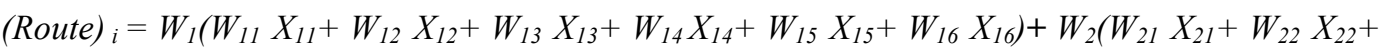
$\left.W_{23} X_{23}+W_{24} X_{24}+W_{25} X_{25}\right)+W_{3}\left(W_{31} X_{31}+W_{32} X_{32}\right)+W_{4}\left(W_{41} X_{41}+W_{42} X_{42}\right)$.

Based on this, this is done in public vehicles by making direct calculations to passengers, in order to obtain the characteristics of passenger travel with public vehicles on a route.

The purpose of this survey is to collect data related to the description of public transport services, including:

1. Origin and destination of passengers on each route.

2. The number of passengers who make a transfer in one trip for each route.

3. Other modes used before and after.

This can be done by multiplying the interview data by an expansion factor. The expansion factor is obtained by the formula:

$$
\text { Expansion Factor }=\frac{A}{B}
$$

Information:

$\mathrm{A}=$ The total number of passengers carried by a public vehicle in one route (population).

$B=$ Number of samples of passengers who were successfully interviewed from the same route.

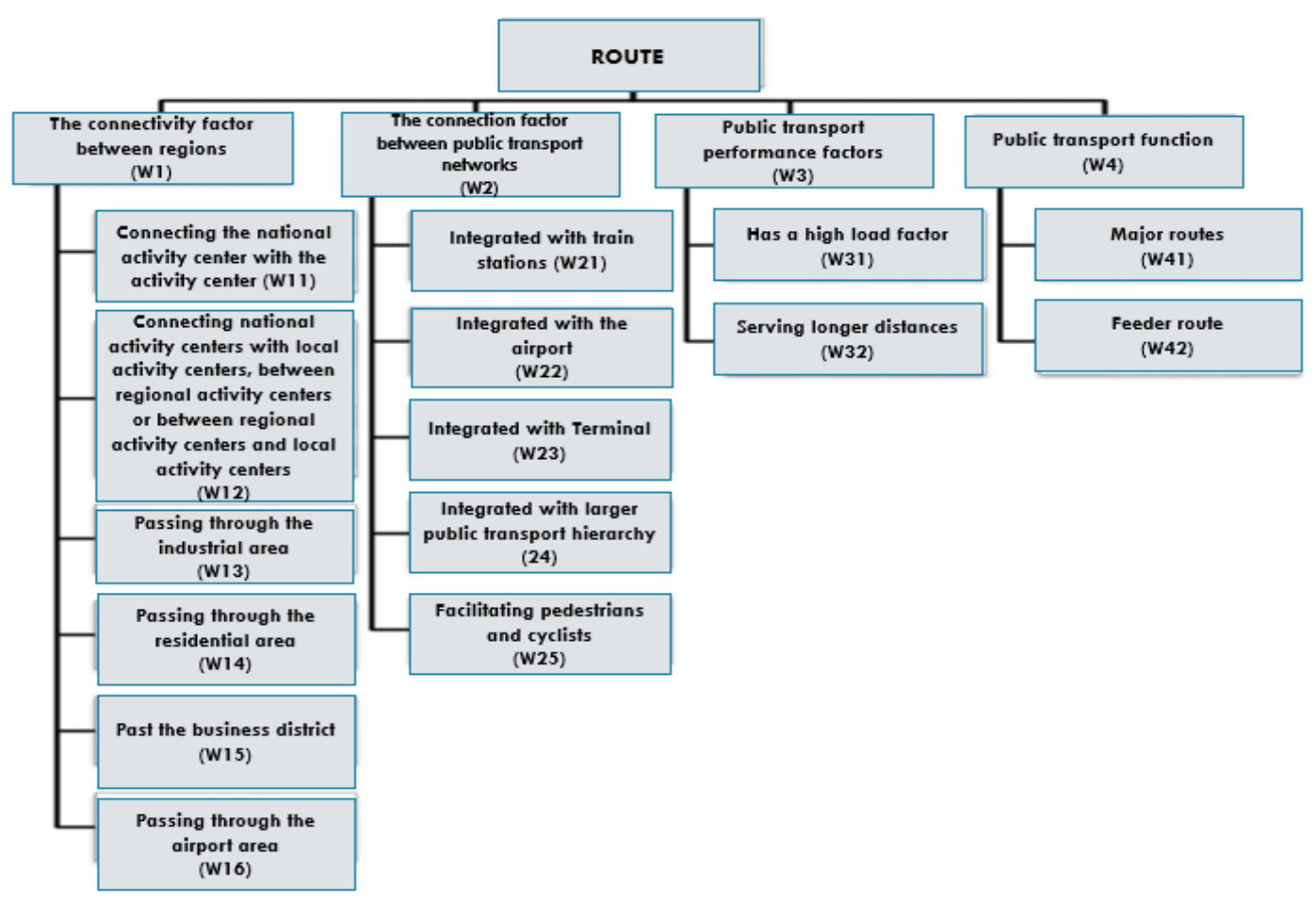

Figure 10. Weighting of the existing route. 


\section{CONCLUSION}

From data analysis and data processing to data analysis and discussion, a study on missing link technical planning in the Jabodetabek area can be concluded as follows in, travel speeds between cities / regencies in Jabodetabek do not reach the target speed of $40 \mathrm{~km} /$ hour. And the speed between regions and within the district / city in the city of Depok. Tangerang Regency and Bekasi Regency had the lowest speed, with the lowest values being $25.06 \mathrm{~km} /$ hour and $25.39 \mathrm{~km} / \mathrm{hour}$. So it is necessary to increase the capacity of the road network to and from Tangerang Regency and Bekasi Regency. For the city of Depok, the average speed that occurs in the city is $28.81 \mathrm{~km} / \mathrm{hour}$, so it is necessary to increase the capacity of the road network in the city of Depok. The TOD area will have a missing link if the TOD has no connectivity with mass public transport nodes located at a distance of more than 800 meters and not on the main route for high capacity mass transportation, such as the Cinere TOD. There is PKN that is not connected by public transportation to other PKN and is not connected to PKW in the same city, namely Cimanggis District, Depok City. The technical planning needed to solve the problem of missing links in the Depok City area can be grouped into the categories of missing link road networks, activity centers, TOD areas, and transportation nodes as well as general transportation service networks.

\section{REFERENCE}

Anonim, 2009. Law Number 22, Concerning Traffic and Road Transportation.

Central Bureau of Statistics, 2018, Depok City in 2018 figures.

Depok City Regional Planning and Development Agency, 2011, Depok City RPJMD Documents 2011 - 2016.

Bogor City Regional Planning and Development Agency, 2015, Depok City Transportation Master Plan Document, 2015.

Budi Sitorus, 2013. Analysis of Mass Transportation Improvement Studies to Reduce Traffic Congestion in DKI JAKARTA. Land Transportation-Transportation Research and Development Agency.

VMS, 2018. Development Technical Planning Document in Transportation Management in Jabodetabek.

MKJI, 1997. Indonesian Road Capacity Manual Document.

Minister of Public Works Decree, 2009. No. 632/KPTS/M/2009 concerning the Status of National Roads throughout Indonesia.

Meyrissa Putri Dewandari, 2018. Feasibility Analysis of Planning and Development of Connecting Roads (Missing Link) between Sikur Village and Paokmotong Village, East Lombok Regency. PLN Technical College.

Minister of Transportation Regulation, 2015. No. 29 of 2015 concerning Minimum Service Standards for Transportation of People with Public Motorized Vehicles on Routes.

Government Regulation 2014. No. 74 of 2014 concerning Road Transportation. Law No. 25 of 2009 concerning Public Services.

Government Regulation, 2006. Road Concerning No. 34 of 2006 concerning Road.

Minister of Transportation Regulation, 2015a. No. 27 of 2015 concerning Minimum Service Standards for Road-based Mass Transportation.

Minister of Transportation Regulation, 2015b. No. 28 of 2015 concerning Minimum Service Standards for Transportation of People with Public Motorized Vehicles Not on Route.

Minister of Transportation Regulation, 2015c. No. 29 of 2015 concerning Minimum Service Standards for Public Transportation of People with Public Motorized Vehicles on Routes. 
Satya Lesmana, 2013. Analysis of Public Transportation Service Management. Gadjah Mada University Yogyakarta

West Java Governor Decree, 2011. No. 620 / Kep.1530/Admrek/2011 concerning Stipulation of Roads according to their Status as Provincial Roads.

Tamin, Ofyar Z. 2000. Transportation Planning and Modeling Second Edition. Bandung: Bandung Institute of Technology.

Tamin, Ofyar Z. 1997. Transportation Planning and Modeling First Edition Bandung: Bandung Institute of Technology.

Tamin, Ofyar Z. 2008. Planning, Modeling \& Transportation Engineering: Theory, Sample Questions and Applications. Bandung: Bandung Institute of Technology.

Syaiful, Lutfi Akbar, 2015. Analisis Pengaruh Kecepatan Lalu lintas Terhadap Kebisingan yang Ditimbulkan Kendaraan Bermotor. ASTONJADRO Jurnal Rekayasa Sipil, 4 (1), pp.13-19. (Indonesian). http://ejournal.uika-bogor.ac.id/index.php/ASTONJADRO/article/view/818

Syaiful, 2015. Tingkat Resistensi Polusi Suara di Depan RSIA Sentosa Bogor. ASTONJADRO Jurnal Rekayasa Sipil, $4 \quad$ (2), pp.57-61.(Indonesian).http://ejournal.uikabogor.ac.id/index.php/ASTONJADRO/article/view/828

Thamrin, Syaiful, 2016. Analisis Kebisingan yang Ditimbulkan Kepadatan Kendaraan Bermotor (Studi Kasus Depan Masjid Assalafiyah, Jl. Raya Sukabumi KM 22 Cigombong, Kabupaten Bogor), ASTONJADRO Jurnal Rekayasa Sipil, 5(2).pp.46-57. (Indonesian). http://ejournal.uikabogor.ac.id/index.php/ASTONJADRO/article/view/839

S Syaiful, A Fadly, 2020. Analysis Of The Effectiveness Of Bus Services Outside Of Campus IPB Dramaga Bogor, ASTONJADRO: JURNAL REKAYASA SIPIL 9 (2), 173-186. http://ejournal.uika-bogor.ac.id/index.php/ASTONJADRO/article/view/3597

M Mubarak, R Rulhendri, S Syaiful, 2020. Perencanaan Peningkatan Perkerasan Jalan Beton Pada Ruas Jalan Babakan Tengah Kabupaten Bogor, ASTONJADRO: JURNAL REKAYASA SIPIL 9 (1), 1-13. (Indonesian). http://ejournal.uikabogor.ac.id/index.php/ASTONJADRO/article/view/2694

Syaiful Syaiful, Sri Wiwoho Mudjanarko, 2019. Noise of Motor Vehicles at from of Baiturrahman Great Mosque Semarang City, THE SPIRIT OF SOCIETY JOURNAL 2 (2), 131-149. DOI: https://doi.org/10.29138/scj.v2i2 https://jurnal.narotama.ac.id/index.php/scj/article/view/902

S Syaiful, N Wahid, 2020. A STUDY OF THE DENSITY OF MOTOR VEHICLES IN FRONT OF HOSPITAL BUNDA MARGONDA DEPOK AGAINST NOISE POLLUTION, THE SPIRIT OF SOCIETY JOURNAL 3 (2), 45-67. https://jurnal.narotama.ac.id/index.php/scj/article/view/1094

S Syaiful, Y Elvira, 2017. CASE STUDY ON USE AREA PARKING AT NEW MARKET CITY SHOPPING CENTER BOGOR, International Journal of Tranportation And Infrastructure (IJTI) 1 (1), 15-23. https://jurnal.narotama.ac.id/index.php/ijti/article/view/330

Law on Road, 2009. Law on Road Traffic and Transportation.

Warpani, Surwardjoko. 1990. Planning a Transport System. Bandung: Bandung Institute of Technology. 